\title{
Online Learning Assessment: Solution in Industrial Revolution 4.0
}

\author{
Furintasari Setya Astuti ${ }^{1,2^{*}}$, Heri Retnawati ${ }^{1}$ \\ ${ }^{1}$ Universitas Negeri Yogyakarta, Indonesia \\ ${ }^{2}$ Eduprime Yogyakarta, Indonesia \\ *Corresponding author. Email: furintasari0024pasca.2021@student.uny.ac.id
}

\begin{abstract}
This study aimed to determine the effectiveness, advantages, and disadvantages of using digital platform in learning assessment. The digital platform discussed in this study is Eduprime, a digital platform that is engaged in assessment. This research uses the mixed method. Data retrieval is done by interview techniques, student questionnaires, and documentation using google forms. The instruments used were interview sheets and student questionnaires. The sample of this research is the principal, homeroom teacher, and teacher of SMA Mandiri Balaraja, as many as 7 respondents, and grade $11^{\text {th }}$ and $12^{\text {th }}$ students of SMA Mandiri Balaraja, totaling 131 respondents. Based on the results of the study, some students stated that the use of digital platforms in the evaluation of learning gave a positive response. This is evidenced by the average percentage of $71.36 \%$ in the good category. Meanwhile, the principal, homeroom teachers, and teachers said that the use of the digital platform (Eduprime) was practical, also said some advantages, disadvantages, and suggestions for learning assessment activities.
\end{abstract}

\section{Keywords: Digital platform, Learning assessment, Online Assessment}

\section{INTRODUCTION}

The 21st century is known as the century of globalization. The 21 st century is marked by a paradigm shift, including education. According to Akgunduz \& Ertepinar in Erdem [1], for centuries, only a small number of people need to have skills such as creativity, critical thinking, and problem solving, still in the $21 \mathrm{st}$ century, every color of the country needs to have these skills. In the field of education, students, teachers, principals, education staff, and all education stakeholders must have these competencies to survive in the 21 st century, which is full of disruption. In another study, the standard skills that must be possessed in the 21 st century are 4Cs (critical thinking, creative thinking, collaboration, and communication), ICTs (technology, media, and information literacy), spiritual values (religious beliefs and spiritual awareness), and character building (teachers' attitudes and scientific attitudes) [2].

Currently, the world is in the phase of industrial revolution 4.0. In industrial revolution era, humans, machines, and products are communicated using the internet [3]. This shift in ways also goes into the political, social, cultural, and educational spheres [4]. The industrial revolution 4.0 has changed the education paradigm. Many things are controlled by artificial intelligence, and gave birth to future educational models [5].

The impact of the COVID-19 pandemic is starting to spread to the world of education [6]. Almost the entire education sector is done digitally. The COVID-19 pandemic has had a negative impact on schools, teachers, students, parents, and even policy makers, so the adoption of technology in education is needed [7]. In addition, to create a creative, innovative, and competitive generation, it can be done by optimizing the use of technology as an educational tool to produce outputs that can adapt and change the environment for the better, including Indonesia [8].

In connection with the development of the paradigm in the industrial revolution 4.0 and in the Covid-19 pandemic where there are rules for online learning, schools use various platforms for learning activities and assessment activities, including SMA Mandiri Balaraja. 
Based on information from the head of the Pendidikan Mandiri Foundation, Mandiri Balaraja senior high school has carried out assessment activities such as middle test assessment, final semester assessment, and final year assessment since 2018. This school used the Eduprime digital platform to carry out these assessment activities.

\subsection{Assessment}

Assessment can be defined as a systematic process of collecting data to obtain information to see the state, ability, or progress of students, curriculum, programs, schools, and educational policies [9], [10]. In terms of determining decisions for students, class assessment is divided into two. They are formative assessment and summative assessment. Formative assessment aims to plan instructional activities, place students into learning sequences, monitor students' progress, diagnose learning difficulties, and give students feedback to students on how to improve [9][11]. Formative assessment can be done throughout the learning activities [11].

Summative assessment functions are reporting about achievement (to students and parents), reporting about effectiveness (to teacher), and assigning grades to students [9]. One example of summative assessment is the final exam [12]. It can also be said that summative assessment can be carried out at the end of the lesson.

\section{MATERIAL \& METHODOLOGY}

\subsection{Data}

This study collected data to see the effectiveness of online learning assessment at SMA Mandiri Balaraja grades 11 and 12 for the 2020/2021 academic year, totaling 131 students. In addition, the data is also in the form of interviews with teachers and school principals, totaling 7 informants. Teachers and principals were interviewed to find out the advantages and disadvantages of digital platforms in accommodating online learning assessment activities.

Data collection techniques using surveys [13] with a questionnaire instrument given to students and an interview sheetto informants. Data collection was carried out using the help of Google Forms [14].

\subsection{Method}

The method used in this research is mixed methods. Questionnaire data totaling 12 items was analyzed to determine the effectiveness of using digital platforms for assessment activities. Meanwhile, data from interviews with teachers and school principals were used to determine the advantages and disadvantages of using digital media for assessment at Mandiri Balaraja senior high school. Questionnaire data analysis was carried out using Table 1 . The results of the questionnaire obtained from the respondents were analyzed using the following formula:
Percentage $=\frac{\text { total score }}{\text { maximum score }} \times 100 \%$

Table 1. Questionnaire data analysis

\begin{tabular}{|l|c|c|}
\hline Answer Category & $\begin{array}{c}\text { Positive statement } \\
\text { score }\end{array}$ & $\begin{array}{c}\text { Negative } \\
\text { statement score }\end{array}$ \\
\hline Strongly agree & 4 & 1 \\
\hline Agree & 3 & 2 \\
\hline Disagree & 2 & 3 \\
\hline Strongly disagree & 1 & 4 \\
\hline
\end{tabular}

Table 2. Criteria percentage of respondent response

\begin{tabular}{|c|l|}
\hline Score Percentage & Criteria \\
\hline $20 \% \leq x \leq 36 \%$ & Strongly poor \\
\hline $36 \%<x \leq 52 \%$ & Poorly \\
\hline $52 \%<x \leq 68 \%$ & Good enough \\
\hline $68 \%<x \leq 84 \%$ & Good \\
\hline $84<x \leq 100 \%$ & Strongly good \\
\hline
\end{tabular}

Table 2 is used to see the effectiveness of using digital platforms in learning assessment activities. To see the adequacy of the sample, the data in this study were applied to the Kaiser Mayer Olkin Measure and Bartlett's Test, resulting in a significance value of less than 0.05. The instrument trial was conducted on 72 students. Using SPSS 26.0 obtained the following results:

Tabel 3. KMO dan Bartlett's Test

\begin{tabular}{|l|l|l|}
\hline \multicolumn{2}{|l|}{$\begin{array}{l}\text { Kaiser-Mayer- Olkin Measurement of } \\
\text { Sampling Adequacy }\end{array}$} & 0,788 \\
\hline $\begin{array}{l}\text { Bartlett's Test } \\
\text { of Sphericity }\end{array}$ & Approx. Chi-Square & 462,755 \\
\cline { 2 - 3 } & df & 66 \\
\cline { 2 - 3 } & Sig. & 0,000 \\
\hline
\end{tabular}

Based on Table 3, the value of Kaiser-Mayer-Olkin MSA 0,778 , shows more than 0,5. Chi-Square value shows 462,755 and Sig 0,000, which is less than 0,05. So we can conclude that sample size 72 is sufficient for factor analysis.

Proof of validity in this study using exploratory factor analysis. Based on SPSS 26.0, the obtained scree plot is presented in Figure 1. 


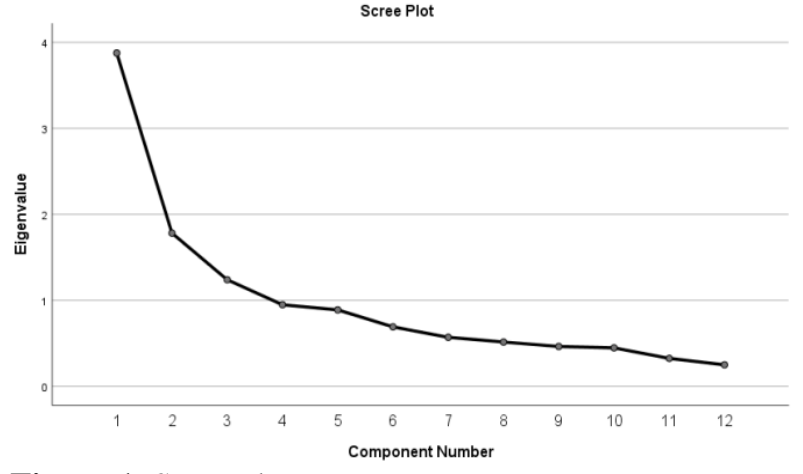

Figure 1. Scree plot

The scree plot is used to identify the number of factors constructed. The formed factor is marked with an eigenvalue of more than 1 [15]. Based on Figure 1, there are three eigenvalues more than 1 , so we can conclude that there are three factors constructed from data.

Based on the three constructed factors, it can be seen the factor loading value of each factor. The factor loading can be seen in Table 4 .

Tabel 4. Eigenvalues and Variance Components of Factor Analysis Results

\begin{tabular}{|c|c|c|c|}
\hline \multirow{2}{*}{ No } & \multicolumn{3}{|c|}{ Initial eigenvalue } \\
\cline { 2 - 4 } & Total & \% of variance & Cummulative \% \\
\hline 1 & 3,877 & 32,305 & 32,305 \\
\hline 2 & 1,782 & 14,851 & 47,155 \\
\hline 3 & 1,240 & 10,329 & 57,485 \\
\hline 4 & 0,949 & 7,906 & 65,390 \\
\hline 5 & 0,889 & 7,411 & 72,802 \\
\hline 6 & 0,692 & 4,765 & 78,567 \\
\hline 7 & 0,571 & 4,754 & 83,321 \\
\hline 8 & 0,515 & 4,293 & 87,614 \\
\hline 9 & 0,463 & 3,862 & 91,475 \\
\hline 10 & 0,448 & 3,730 & 95,205 \\
\hline 11 & 0,325 & 2,707 & 97,912 \\
\hline 12 & 0,251 & 2,088 & 100,00 \\
\hline
\end{tabular}

Based on Table 4, the cumulative percentage of factor loading is $57.485 \%$. The next step is to look at the distribution of each factor. The distribution of items can be seen in Table 5. Based on Table 5, there are 7 items in factor 1: items $1,3,5,6,7,9,12$. Factor 2 has 3 items: items 8, 10, 11. Factor 3 has 2 items: items 2 and 4.
Tabel 5. Distribution of items

\begin{tabular}{|l|l|}
\hline Factor & Items \\
\hline 1 & $1,3,5,6,7,9,12$ \\
\hline 2 & $8,10,11$ \\
\hline 3 & 2,4 \\
\hline
\end{tabular}

Based on the constructed factor, the factor name is given. The first factor is the ease use of the Eduprime digital platform, the second factor is the benefits of digital platform usage, the third factor is limitation in internet data packages/ internet connectivity and low bandwidth. Based on KMO-MSA, eigenvalue, distribution of factor, we can conclude that instrument is valid. [15]

The instrument for Reliability estimation uses Cronbach alpha formula. The value of each indicator uses likert scale. Formula alpha Cronbach [16] is following:

$$
\alpha=\left[\frac{N}{N-1}\right]\left[\frac{\sigma_{t}^{2}-\sum_{i=1}^{N} \sigma_{i}^{2}}{\sigma_{t}^{2}}\right]
$$

Using SPSS 26.0, the reliability estimation in this study resulted in a reliability coefficient of 0.762 . Because the reliability coefficient is more than 0.6 , it can be concluded that the questionnaire on the effectiveness of the digital platform for the assessment is reliable [16].

\section{RESULT \& DISCUSSION}

Descriptive statistics of the overall data of this study are presented in Table 6. Based on Table 6, it can be seen that the average score of students on the questionnaire on the effectiveness of using digital platforms for learning assessment activities is 34.25, with a standard deviation of 3.96. The maximum score in the results of this study is 46 , while the minimum score is 23 .

Table 6. Descriptive statistic

\begin{tabular}{|l|c|}
\hline \multicolumn{1}{|c|}{ Descriptive } & Value \\
\hline Average & 34,25 \\
\hline Standard deviation & 3,96 \\
\hline Maximum score & 46 \\
\hline Minimum score & 23 \\
\hline
\end{tabular}


The results of the descriptive statistics of the two factors from the result of exploratory factor analysis are shown in Table 7.

Table 7 . Descriptive statistics of each factor

\begin{tabular}{|l|c|c|c|}
\hline \multicolumn{1}{|c|}{ Description } & Factor 1 & Factor 2 & Factor 3 \\
\hline Average & 20,94 & 8,99 & 4,33 \\
\hline $\begin{array}{l}\text { Standard } \\
\text { deviation }\end{array}$ & 2,59 & 1,81 & 1,22 \\
\hline Maximum score & 28 & 12 & 8 \\
\hline Minimum score & 7 & 3 & 2 \\
\hline
\end{tabular}

Based on Table 7, factor 1 has an average of 90,94 with a maximum score of 28 , a minimum score of 7 , and a standard deviation of 2,59. Factor 2 has an average of 8,99 with a maximum score of 12 , a minimum score of 3 , and a standard deviation of 1.81 . Factor 3 has an average of 4,33 with a maximum score of 8 , a minimum score of 2 , and a standard deviation of 1.22 . Table 8 shows the effectiveness level of digital platforms usage in learning assessments.

Table 8 . Effectiveness of digital platform usage in learning assessment

\begin{tabular}{|l|c|}
\hline \multicolumn{1}{|c|}{ Descriptive } & Value \\
\hline Score average & 34,25 \\
\hline Maximum score & 48 \\
\hline Percentage & $71,35 \%$ \\
\hline
\end{tabular}

Overall, the effectiveness of using digital platforms for learning assessment activities is 71.35 , or in the good category. Effectiveness based on factor 1, namely the ease of digital platforms use in learning assessment activities, can be seen in Table 9. Meanwhile, the effectiveness based on factor 2, namely benefits of the use of digital platform in assessment activities, can be seen in Table 10.

Table 9. Effectiveness of ease of use digital platform in learning assessment

\begin{tabular}{|l|c|}
\multicolumn{1}{|c|}{ Descriptive } & Value \\
\hline Score average & 20,94 \\
\hline Maximum score & 28 \\
\hline Percentage & $74,78 \%$ \\
\hline
\end{tabular}

Table 10. Benefits of use of digital platform

\begin{tabular}{|l|c|}
\hline \multicolumn{1}{|c|}{ Descriptive } & Value \\
\hline Score average & 8,99 \\
\hline Maximum score & 12 \\
\hline Percentage & $74,87 \%$ \\
\hline
\end{tabular}

The effectiveness based on factor 3, namely limitation in internet data packages/ internet connectivity and low bandwidth in learning assessment activities, can be seen in Table 11 .

Table 11. Effectiveness of limitation in internet data packages/ internet connectivity and low bandwidth

\begin{tabular}{|l|c|}
\hline \multicolumn{1}{|c|}{ Descriptive } & Value \\
\hline Score average & 4,33 \\
\hline Maximum score & 8 \\
\hline Percentage & $54,10 \%$ \\
\hline
\end{tabular}

In Table 11, it can be seen that the effectiveness of using digital platforms in learning assessment activities is $71,35 \%$ and is in the good category. If differentiated based on factor 1, the study results show the ease of use of the digital platform, namely Eduprime in learning assessment activities, which is easy to use with a percentage of $74.78 \%$ in the good category. This is in line with the results of research conducted by Zulkefli et. al. [17] that one of the advantages of using digital platforms in learning activities is the ease of use.

For factor 2, the benefits of digital platform use, $74,87 \%$ students get benefits such us more motivate than using paper-based test, upgrade their skill in computer, etc.

Factor 3, in terms of quota and network constraints, shows $54,10 \%$. It can be said that most students experience quota and network constraints. One of the weaknesses in using digital platforms in learning is the limitation of internet data packages/internet connectivity and low bandwidth. [18],[19],[20] .

The results of teacher and principal interviews related to the use of digital platforms in learning assessment activities are as follows:

1. Assist students in online learning assessment activities.

2. The process of presenting test questions is easy because uploading questions can be done in many questions simultaneously.

3. Speeds up the correction time because the results can be obtained in real time. This is in line with the results of research conducted by Alruwais et. al. [21] that one advantage of eassessment is reducing the time and effort of the teacher.

4. Practical, because it can be used using a personal computer or android. Assist students in online learning assessment activities.

In addition to the advantages of using digital platforms in learning assessment activities, there are weaknesses in using digital platforms in learning assessment activities such as: 
1. Low internet connectivity because the platform is based on full online.

2. Not all teachers are technology literate, so it is difficult to implement digital platforms, especially teachers of exact subjects [22].

Based on the identification of the weaknesses and strengths of using digital platforms in learning assessment activities, informants also provide suggestions to make it easier to use digital platforms in learning assessment activities, they are:

1. Development of Artificial Intelligence technology to upload questions using photos such as Google Camera or Google Lens.

2. Improvement of formula writing

3. Training on the use of the platform regularly.

\section{CONCLUSION}

This study concludes that in general the students stated that the use of digital platforms in the evaluation of learning gave a positive response. This is evidenced by the average percentage of $71.36 \%$ in the good category. If viewed from factor 1 , namely the ease of use of digital platforms in learning evaluation, it is in the good category with a percentage of $74.78 \%$. When viewed from factor 2 , namely benefits of the use of digital platform, it is in the good category with a percentage of $74.87 \%$. When viewed from factor 3 , namely quota and network constraints, the majority stated that they were constrained by quotas and networks in learning assessment activities using digital platforms because they were fully online. Meanwhile, principals, homeroom teachers, and teachers said that using the digital platform, Eduprime, is practical.

\section{ACKNOWLEDGEMENTS}

The author would like to thank Eduprime as the digital platform and the entire family of SMA Mandiri Balaraja for fully supporting this research.

\section{REFERENCES}

[1] C. Erdem, "C Hapter O Ne I Nternational a Ccounting and," Researchgate, no. September, pp. 1-33, 2019.

[2] Afandi, Sajidan, M. Akhyar, and N. Suryani, "Development frameworks of the Indonesian partnership 21 st -century skills standards for prospective science teachers: A Delphi study," J. Pendidik. IPA Indones., vol. 8, no. 1, pp. 89-100, 2019, doi: 10.15294/jpii.v8i1.11647.

[3] S. S. Fernández-Miranda, M. Marcos, M. E. Peralta, and F. Aguayo, "The challenge of integrating Industry 4.0 in the degree of Mechanical Engineering," Procedia Manuf., vol. 13, pp. 1229-1236, 2017, doi: 10.1016/j.promfg.2017.09.039.

[4] Husni and Y. F. Dafik, "Management of Islamic higher education in the 4.0 industrial revolution," Int. J. Educ. Stud., vol. 15, no. 2, pp. 87-107, 2018, [Online]. Available: http://fsshjournal.org/index.php/es/article/view/52.

[5] A. A. Shahroom and N. Hussin, "Industrial Revolution 4.0 and Education," Int. J. Acad. Res. Bus. Soc. Sci., vol. 8, no. 9, pp. 314-319, 2018, doi: 10.6007/ijarbss/v8-i9/4593.

[6] A. Abidah, H. N. Hidaayatullaah, R. M. Simamora, D. Fehabutar, and L. Mutakinati, "The Impact of Covid-19 to Indonesian Education and Its Relation to the Philosophy of 'Merdeka Belajar,"' Stud. Philos. Sci. Educ., vol. 1, no. 1, pp. 38-49, 2020, doi: 10.46627/sipose.v1i1.9.

[7] E. M. Onyema, F. Obafemi, S. Sen, and A. Sharma, "Impact of Coronavirus Pandemic on Education," J. Educ. Pract., no. May, 2020, doi: 10.7176/jep/11-13-12.

[8] D. Lase, "Pendidikan Islam di Era Revolusi Industri 4.0," pp. 34-0, 2019, doi: 10.31219/osf.io/8xwp6.

[9] A. J. Nitko and S. M. Brookhart, Educational Assessment of Students Pearson New International Edition. .

[10] A. M. Yusuf, Asesmen dan Evaluasi.pdf, Pertama. Jakarta: Kencana, 2015.

[11] F. M. F. Lau and G. Sou, "Assessment for learning: Hong Kong needs territory-wide system assessment (TSA) or not," Public Adm. Policy, vol. 21 , no. 1 , pp. $68-84$, 2018, doi: $10.1108 /$ pap06-2018-004.

[12] A. J. Swart, "Evaluation of final examination papers in engineering: A case study using bloom's taxonomy," IEEE Trans. Educ., vol. 53, no. 2, pp. 257-264, 2010, doi: 10.1109/TE.2009.2014221.

[13] M. D. Miller, R. L. Linn, and N. E. Gronlund, Measurement and Assessment in Teaching, 10th ed. New Jersey: Pearson, 2009.

[14] A. Mubarok et al., "Analisis Kepuasan Pengguna Layanan Google-Forms Sebagai Media Survey Online Menggunakan Delone \&," vol. 7, no. 2, pp. 192-198, 2020.

[15] H. Retnawati, Analisi Kuantitatif Instrumen Penelitian. Yogyakarta: Parama Publishing, 2016.

[16] M. J. Allen and W. M. Yen, Introduction to measurement theory. Belmont, CA: Wadsworth, Inc, 1979.

[17] N. A. M. Zulkefli, H. Hashim, and S. Syahrin, "Evaluating e-learning google classroom tools for computer science subjects during covid-19 pandemic," Int. J. Adv. Trends Comput. Sci. Eng., vol. 9, no. 4, pp. 6251-6258, 2020, doi: 10.30534/ijatcse/2020/304942020.

[18] M. Al-Balas et al., "Correction to: Distance learning in clinical medical education amid COVID-19 pandemic in Jordan: current situation, challenges, and perspectives (BMC Medical Education, (2020), 20, 1, (341), 10.1186/s12909. 
020-02257-4)," BMC Med. Educ., vol. 20, no. 1, pp. 1-7, 2020, doi: 10.1186/s12909-020-02428-3.

[19] F. Farooq, F. A. Rathore, and S. N. Mansoor, "Challenges of online medical education in Pakistan during COVID-19 pandemic," J. Coll. Physicians Surg. Pakistan, vol. 30, no. 1, pp. S67S69, 2020, doi: 10.29271/jcpsp.2020.Supp1.S67.

[20] W. A. S. Wan Hassan, A. Ariffin, F. Ahmad, S. N. M. Sharberi, M. I. Nor Azizi, and S. N. Zulkiflee, "Covid-19 pandemic: Langkawi vocational college student challenge in using google classroom for teaching and learning (t\&l)," Int. J. Adv. Trends Comput. Sci. Eng., vol. 9, no. 3, pp. 3299-3307, 2020, doi: 10.30534/ijatcse/2020/127932020.

[21] N. Alruwais, G. Wills, and M. Wald, “Advantages and Challenges of Using e-Assessment," Int. J. Inf. Educ. Technol., vol. 8, no. 1, pp. 34-37, 2018, doi: 10.18178/ijiet.2018.8.1.1008.

[22] U. S. A. Osuji, "The use of e-assessments in the Nigerian higher education system," Turkish Online J. Distance Educ., vol. 13, no. 4, pp. 1-13, 2012, doi: 10.17718/tojde.25466. 